\title{
The Effect of Early Removal of Mesiodens for the Correction of Central Incisor Rotation
}

\author{
Jueun Lee, Youngjin Kim, Hyunjung Kim, Soonhyeun Nam
}

Department of Pediatric Dentistry, School of Dentistry, Kyungpook National University

\section{Abstract}

Mesiodens is defined as a supernumerary tooth in the premaxillary region. It can cause several clinical manifestations in normal eruption and position of adjacent teeth, such as displacement and impaction. Although the mesiodens accompanied by a clinical complication is indicated for removal, the optimal time of mesiodens removal is still controversial. Some authors suggest immediate intervention defining the removal of mesiodens as soon as possible after the first detection. On the other hand, others recommend delayed intervention which denotes the removal of mesiodens after complete root development of adjacent teeth.

This case report is presented with three cases of spontaneous correction and proper alignment of rotated maxillary central incisors by extraction of mesiodens when the crowns of rotated incisors were completely formed while the roots of them were at an early developmental stage.

Key words : Mesiodens, Rotated central incisors, Early root developmental stage, Spontaneous correction

\section{Introduction}

The mesiodens is the most frequent supernumerary tooth which presents in the premaxillary region. This term is first called by Bolk in 1931' . The etiology of mesiodens is still unknown, but the hypothesis of dental lamina hyperactivity, the atavistic theory and dichotomy theory have been proposed to explain this anomaly ${ }^{2}$.

Mesiodens could be remained for many years without any pathological problems. However, it is usually involved in a variety of clinical complications, such as delayed eruption, impaction, root resorption, abnormal diastema, cyst formation and rotation of adjacent teeth ${ }^{3)}$.

Although mesiodens should undoubtedly be removed if any of the above referred complications are found, conservative approach such as observation is recommended if the mesiodens does not show any evidences of associated clinical disturbances ${ }^{2}$.

The ideal time for the surgical removal of an unerupted mesiodens is controversial. Considering the lack of $\mathrm{co}^{-}$ operation of a young child and the risk of injury to the developing teeth, some studies have suggested that the optimal time to remove impacted mesiodens is when the root formation of the adjacent permanent incisors is $\mathrm{al}^{-}$ most completed. On the other hand, others have recommended the early removal of mesiodens since delayed removal could lead to losing of the eruption space and failure of self-correction of the displaced teeth.

The purpose of this report is to show three cases of the rotated maxillary central incisors which were spontaneously corrected by early extraction of mesiodens and to highlight the importance of early diagnosis and manage-

Corresponding author : Soonhyeun Nam

Department of Pediatric Dentistry, School of Dentistry, Kyungpook National University

Tel: +82-53-600-7211 / Fax: +82-53-426-6608 / E-mail: shnam@knu.ac.kr

Received October 15, 2013 / Revised November 27, 2013 / Accepted November 28, 2013

※ This research was supported by Kyungpook National University Research Fund, 2013. 
ment of mesiodens.

\section{II . Case Reports}

\section{Case I}

A 6-year-old boy visited the Department of Pediatric Dentistry at Kyungpook National University Dental Hospital with the chief complaint of impacted mesiodens. Clinical examination revealed a deciduous dentition with no eruption of central incisors. Radiographic examination showed the rotated maxillary right permanent central incisor due to the presence of two mesiodens (Fig. 1A,B). The rotated maxillary right permanent central incisor had the completely formed crown without root development.

Six months after the patient's first visit, a periapical radiograph revealed the erupted maxillary left perma- nent central incisor. On the contrary, the maxillary right permanent central incisor did not erupt and was still rotated. At that time, the crown of maxillary right permanent central incisor was completely developed while its root was at an early developmental stage (Fig. 1C). Then, both mesiodens were surgically extracted using $10^{-}$ cal anesthesia to help eruption of the maxillary right permanent central incisor. Since the patient had good cooperation during the treatment, we could remove the impacted mediodens without difficulty.

Radiographic observation of the patient continued for 4 years. During this time, the rotated maxillary right permanent central incisor erupted completely and corrected itself without orthodontic treatment (Fig. 1D,E). Four years later, we could find full eruption and proper alignment of both maxillary central incisors on the arch (Fig. $1 \mathrm{~F})$. Also, there were no damages on the vitality of both maxillary permanent central incisors.
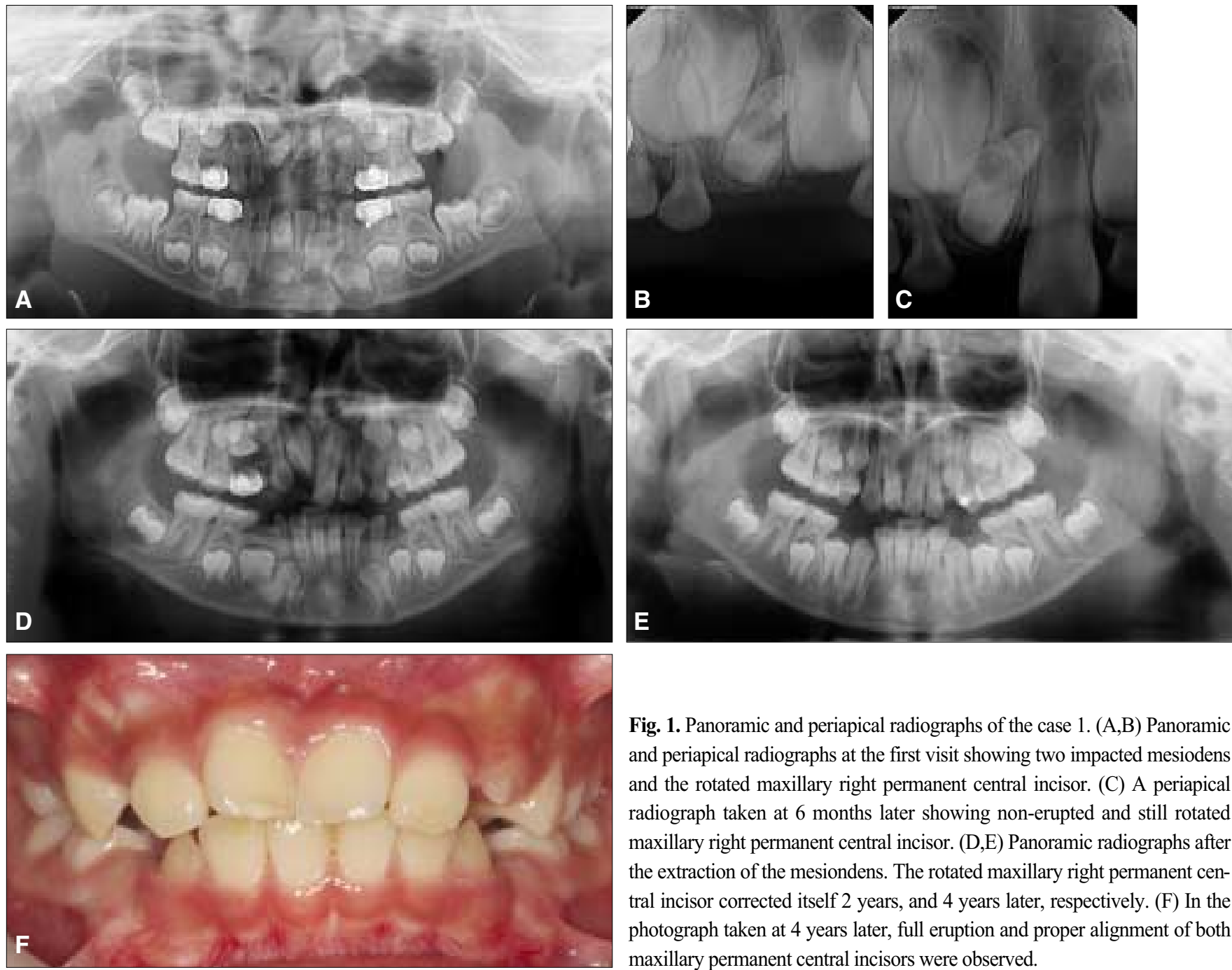

Fig. 1. Panoramic and periapical radiographs of the case 1. (A,B) Panoramic and periapical radiographs at the first visit showing two impacted mesiodens and the rotated maxillary right permanent central incisor. (C) A periapical radiograph taken at 6 months later showing non-erupted and still rotated maxillary right permanent central incisor. (D,E) Panoramic radiographs after the extraction of the mesiondens. The rotated maxillary right permanent central incisor corrected itself 2 years, and 4 years later, respectively. (F) In the photograph taken at 4 years later, full eruption and proper alignment of both maxillary permanent central incisors were observed. 


\section{Case II}

A 5-year-old boy was presented with the failure of eruption of the maxillary permanent central incisors. Clinical examination revealed a mixed dentition including the mandibular permanent incisors and the first permanent molars. An erupted tuberculated-shaped mesiodens was found on the area corresponding to the maxillary right primary central incisor. Panoramic and periapical radiographs showed the presence of the maxillary left primary central incisor and the delayed eruption of the rotated maxillary left permanent central incisor due to the presence of another mesiodens which was impacted. The crown of the maxillary left permanent central incisor was completely developed, but the root of it was seemed to be at its initial stage (Fig. 2A,B). Then, the maxillary left primary central incisor and both mesiodens were removed under local anesthesia in an attempt to eliminate the hindrance of the eruption path of the maxillary permanent central incisors. There were no management problems, because the patient cooperated well on all surgical procedures.
At the 15-day recall after the removal, we could find the rotated maxillary left permanent central incisor in a periapical radiograph (Fig. 2C). However, a radiograph taken at 10 months later showed the spontaneous recovery of the rotated maxillary left permanent central incisor (Fig. 2D). Thirty-three months had elapsed before the patient revisited our section for his treatment of the traumatized mandibular right canine (Fig. $2 \mathrm{E}$ ). The panoramic radiograph taken at the time indicated normal eruption and acceptable alignment of the maxillary left permanent central incisor (Fig. 2F). In addition, the vitality of both maxillary permanent central incisors was intact.

\section{Case III}

A 5-year-old boy was referred from a local clinic for treatment of mesiodens. Clinical observation disclosed a deciduous dentition including the dental carious lesions on the interproximal surfaces of the maxillary primary incisors. Radiographic evaluation showed the presence of the rotated maxillary right permanent central incisor
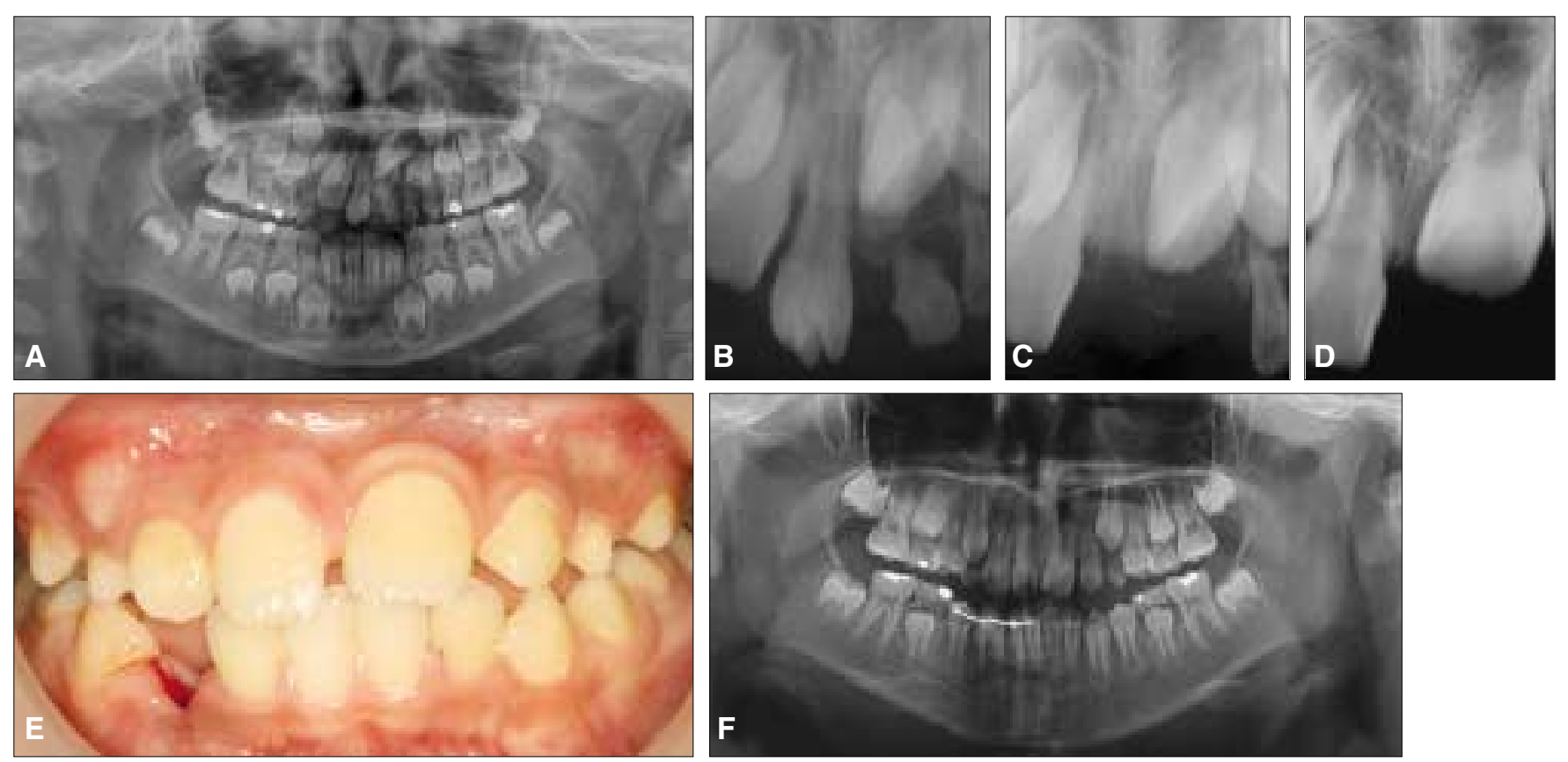

Fig. 2. Panoramic and periapical radiographs of the case 2. (A,B) Panoramic and periapical radiographs at the first visit showing two mesiodens and the rotated maxillary left permanent central incisor. (C,D) Periapical radiographs after the extraction of both mesiodens. The rotated maxillary left permanent central incisor showed self-correction 15 days, and 10 months later, respectively. (E,F) Thirty-three months later, the patient revisited for treatment of the traumatized mandibular right canine. A panoramic radiograph taken at that time showed normal eruption and acceptable alignment of the maxillary left permanent central incisor. 
which had complete crown formation without root development. Also, it revealed an impacted mesiodens lying between the maxillary permanent central incisors (Fig. 3A). On a presurgical interview with the parents, we could predict the good cooperation of the patient under dental situation.

Six months later, we could find non-erupted and still rotated maxillary right permanent central incisor on a periapical radiograph (Fig. 3B). Then, we surgically extracted both maxillary primary central incisors and impacted mesiodens under local anesthesia.

At the 6-month recall after the removal, a periapical radiograph still revealed slightly rotated maxillary right permanent central incisor (Fig. 3C). However, the panoramic radiograph taken at fifteen months later disclosed the spontaneous correction of the rotated maxillary right permanent central incisor (Fig. 3D). Two years later, both maxillary permanent central incisors erupted completely and were aligned in proper position (Fig. 3E). Also, they normally responded to the cold test or electric pulp vitality test indicating no evidence of damages on the vitality.

\section{Discussion}

The early surgery of the mesiodens could cause some clinical problems. First of all, the concern about iatrogenic damage to the developing adjacent permanent incisors is the principle reason to avoid early removal before the eruption of the adjacent teeth. Because of this, many authors have suggested the delayed extraction of the impacted mesiodens until the root growth of the adjacent teeth is almost completed ${ }^{4.5)}$. In addition, some have advocated that the surgical removal of the mesiodens is contraindicated during 5- to 7-year-old children whose incisors erupt actively because the surgical process can result in the loss of vitality and impaired development by damaging to the blood supply of the developing teeth ${ }^{6}$. Moreover, several reports have suggested observation when the mesiodens is non-inverted and seems to erupt spontaneously without interfering with normal eruption and development of existing dentition ${ }^{7)}$.

In contrast, others have reported that mesiodens should be removed as early as possible to prevent further complications, especially when the mesiodens dis-
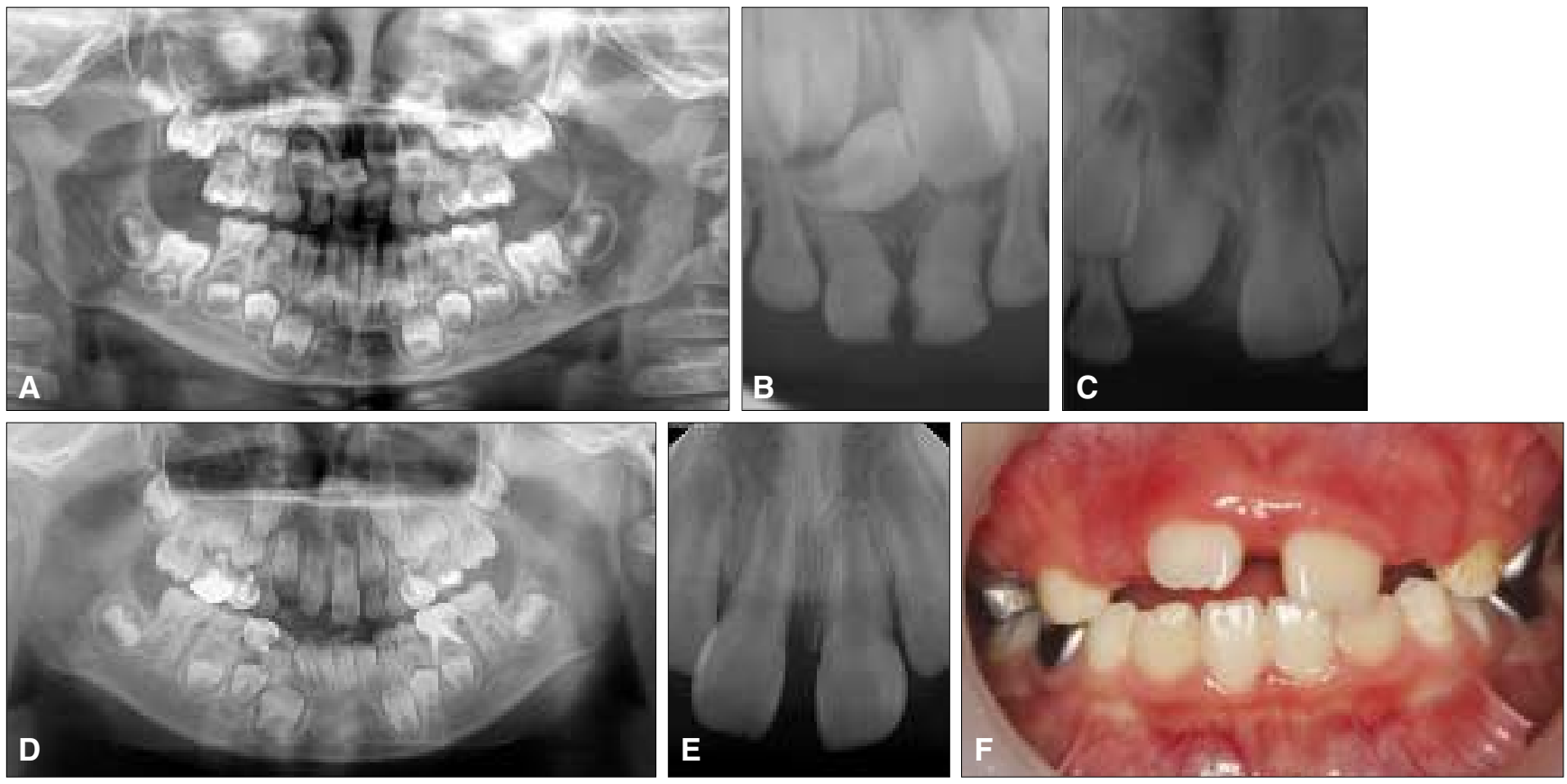

Fig. 3. Panoramic and periapical radiographs of the case 3. (A) Panoramic radiograph at the first visit showing the rotation of the maxillary right permanent central incisor due to the presence of mesiodens. (B) Periapical radiograph taken at 6 months later still showed rotated maxillary right permanent central incisor. (C,D,E) Panoramic and periapical radiographs after the extraction of mesiodens. The spontaneous recovery of the rotated maxillary right permanent central incisor was found 6 months, 15 months, and 2 years later, respectively. (F) Fifteen months later, both maxillary permanent central incisors erupted normally and were aligned in proper position. 
turbs the eruption of adjacent teeth ${ }^{8-10}$. Rotberg ${ }^{8)}$ stated that eruption and developmental problems of the permanent incisors are more likely to occur in a child whose surgical extraction of mesiodens is performed after the age of 7 than a child who had the removal before the age of 5. Omer et al. ${ }^{10)}$ addressed that the root resorption of the adjacent permanent teeth is commonly showed when the surgical removal is delayed until after the age of 10 . Moreover, Nazif et al. ${ }^{11)}$ reported that the early surgical intervention does not seem to result in the loss of vitality of the adjacent teeth. Furthermore, some reports have informed that self-correction and proper alignment of the rotated adjacent teeth are obtained by the early removal of mesiodens that are related to the rotation of adjacent teeth $^{9)}$. Omer et al. ${ }^{10)}$ reported that the spontaneous recovery of the rotated permanent incisors is only found before the age of 9 . They also added that, in case of malalignment, it is not found when the mesiodens is $\mathrm{re}^{-}$ moved at 4- to 5-year-old.

This case report describes three patients who had the rotated maxillary central incisor due to the presence of mesiodens. Although the patients were young children aged 5 to 6 , we removed the mesiodens as soon as possible after the first diagnosis in order to prevent the eruption disturbance or space loss of the maxillary permanent central incisors. When the mesiodens was removed, the crowns of rotated maxillary central incisors were completely developed while the roots of them were at an early developmental stage. As time progresses, spontaneous eruption and self-correction of the rotated incisors took place without the need of orthodontic treatment because there was enough space for eruption. In addition, an early approach is considered as a factor to effect spontaneous derotation before root formation is completed.

In all cases, there were no needs for additional methods of anesthesia or sedation because all patients cooperated well even during the treatment like anesthesia and extraction. Also, there were no damages on vitality of the adjacent teeth.

The relapse tendency of the orthodontically derotated teeth has been already mentioned in many literatures. It is principally caused by transseptal fibers which do not respond well to tooth movement because they have slower remodeling rate and are organized based on their positional relationship with the adjacent teeth ${ }^{12-14}$. Therefore, transseptal fiberectomy and overcorrection with long retention period have been suggested in order to reduce the relapse and stabilize the orthodontically derotated teeth ${ }^{14)}$. However, Reitan ${ }^{13)}$ has suggested that the easiest way to remove the relapse problem of the ro- $^{-}$ tated teeth is correcting the direction of the rotated teeth before the complete development of apical portion of the root. This is supported by the fact that the transseptal fibers are organized at the later developmental stage of the root formation ${ }^{12)}$. Therefore, in this case report, it is considered that the extraction of the mesiodens before the gingival fiber system was fully developed plays a crucial role in the self-correction of the rotated incisors.

There are a variety of opinions on an early extraction. Some authors have suggested the removal of the mesiodens prior to eruption of the central incisors ensuring the normal eruption of the adjacent teeth ${ }^{15}$. Rotberg ${ }^{8)}$ has recommended the removal of the mesiodens before the age of five in order to prevent the developmental disturbance of developing adjacent teeth. Hogstrom et al. ${ }^{16)}$ has suggested the removal of the mesiodens before the root development of the adjacent incisors is completed. While, the immediate removal after the first diagnosis is widely recommended ${ }^{13)}$. In this case report, it is considered that the removal of the mesiodens at the initial root developmental stage of the adjacent incisors is a factor to bring about self-correction and better alignment of the incisors.

However, surgical removal of a mesiodens in the primary dentition is usually not recommended because the surgical procedure could lead to the displacement or damage to the developing tooth buds. Another reason is that the primary supernumerary teeth generally erupt into the oral cavity due to the presence of the wide interdental spaces ${ }^{17)}$.

Although early removal of impacted mesiodens is justified to prevent its interference of the eruption of adjacent teeth, observation is recommended in the following situations: the case with unerupted symptomless mesiodens which has no effect on the dentition or normally positioned mesiodens which has possibility to erupt spontaneously ${ }^{11}$. Removal criteria of mesiodens can be varied into its type. Conical mesiodens can erupt into the oral cavity if its crown points inferiorly. However, tuberculate mesiodens rarely erupts itself into the oral cavity but rather delays eruption of the neighboring incisors. A supplemental mesiodens which resembles the tooth of the normal series is more frequent in primary dentition and rarely remains unerupted ${ }^{18)}$. Some reports have described that the type of supernumerary tooth has no effect on whether the permanent tooth would erupt 
spontaneously ${ }^{19)}$. However, Patchett ${ }^{20)}$ has addressed that the permanent incisor associated with conical mesiodens is almost twice as likely to erupt spontaneously then the incisor associated with tuberculate one. Therefore, the management of mesiodens should be evaluated on an individual basis to determine the best method.

This case report has some limitations, such as less number of the cases presented and difficulties in identifying shape and location of mesiodens since 2-dimensional images were only taken. In order to overcome the limitations of this report, it is essential to have longterm studies with many cases. In addition, a computed tomography for 3-dimensional image is required to $\mathrm{de}^{-}$ termine exact position of mesiodens and figure possible eruption space for rotated teeth. Furthermore, there should be additional studies for rotation severity and degree of root development of rotated teeth which affect the spontaneous recovery of the rotated teeth.

One of the excessive concerns about the early removal is the behavior management of a young child. Although the surgery could create dental phobia in young children, a careful preoperative history check and suitable methods of anesthesia and sedation can help this problem. For example, if a child has a history of anxiety, nitrous oxide-oxygen sedation or general anesthesia could provide better behavior control during surgical procedure.

In conclusion, early diagnosis of a mesiodens is necessary to avoid or minimize the associated complications. The diagnosis of mesiodens is usually made through radiographic examination because of the asymptomatic characteristic of mesiodens. Thus, clinicians should be aware that regular full-mouth radiographic monitoring and continual follow-ups of mesiodens are required for an accurate diagnosis in a preschool period. Also, we should make decisions on appropriate timing of surgical removal of mesiodens for each individual cases with careful consideration of the pros and cons.

\section{Summary}

Early detection and removal of mesiodens play a crucial role in minimizing the further sequela. This case report describes three cases of the spontaneous recovery of rotated permanent incisors by early removing the mesiodens; its removal was performed when the adjacent incisors have the completely developed crowns while the roots of them were at an early developmental stage or not formed. Moreover, there are no damages on the vitality of adjacent permanent incisors.

Therefore, early intervention is well worth considering in order to avoid further surgical or orthodontic treatment in the cases of rotation of permanent incisors due to the presence of mesiodens.

\section{References}

1. Bolk L : Die Ueberzahnlinger Oberen Incisiven des Menschen. Deutsche Monatsch Zahnh, 35:185, 1931.

2. Sandhu V : Management of Torsiversion of a Tooth Secondary to a Mesiodens. Indian Journal of Dental Education, 4:61-63, 2011.

3. Huang WH, Tsai TP, Su HL : Mesiodens in the primary dentition stage: a radiographic study. $A S D C J$ Dent Child, 59:186-189, 1992.

4. Baysal MC : Supernumerary teeth in children. Dent Digest, 70:506-509, 1964.

5. McDonald RE, Avery DR : Diagnosis and correction of minor tooth irregularities in the developing dentition, in McDonald RE, Avery DR : Dentistry for the Child and Adolescent, $3^{\text {th }}$ edition, St. Louis, The CV Mosby Co, p442, 1978.

6. Stermer EM, Hurlen B, Humerfelt D : Changing positions of supernumerary teeth in the premaxilla : A radiographic study. J Dent Child, 52:428-430, 1985

7. Williams DW : The early eruption of a superanumerry tooth (mesiodens). Br Dent J, 140:209-210, 1976.

8. Rotberg SJ : Early versus late removal of mesiodens : a clinical study of 375 children. The Compendium of Continuing Education, 2:115-120, 1984.

9. Weber FN : Supernumerary teeth. Dent Clin North Am, 1:509-517, 1964.

10. Omer RS, Anthonappa RP, King NM : Determination of the optimum time for surgical removal of unerupted anterior supernumerary teeth. Pediatr Dent, 32:14-20, 2010.

11. Nazif MM, Ruffalo RC, Zullo T : Impacted supernumerary teeth: a survey of 50 cases. J Am Dent Assoc, 106:201-204, 1983.

12. Ten Cate : Oral histology: development, structure, and function. $7^{\text {th }}$ edition, Louis The CV Mosby Co, 2008.

13. Reitan K : Tissue rearrangement during retention of 
orthodontically rotated teeth. Angle Orthod, 29:105113, 1959.

14. Edwards JG : A study of the periodontium during orthodontic rotation of teeth. Am $J$ Orthodont, 54:441-461, 1968.

15. Atwan SM, Turner D : Early intervention to remove mesiodens and avoid orthodontic therapy. Genet Dent, 48:166-169, 2000.

16. Högström A, Andersson L : Complications related to surgical removal of anterior supernumerary teeth in children. ASDC J Dent Child, 54:341-343, 1987.

17. Solares $R$ : The complications of late diagnosis of anterior supernumerary teeth : case report. ASDC J Dent Child, 57:209-211, 1990.
18. Mukhopadhyay S : Mesiodens: a clinical and radiographic study in children. J Indian Soc Pedod Prev Dent, 29:34-38, 2011.

19. Mitchell L, Bennett TG : Supernumerary teeth causing delayed eruption - a retrospective study. $\mathrm{Br}$ J Orthod, 19:41-46, 1992.

20. Patchett CL, Crawford PJ, Cameron AC, Stephens $\mathrm{CD}$ : The management of supernumerary teeth in childhood - a retrospective study of practice in Bristol Dental Hospital, England and Westmead Dental Hospital, Sydney, Australia. Int J Paediatr Dent, 11:259-265, 2001. 
국문초록

\title{
정중과잉치 조기 발거에 따른 상악 영구중절치 회전의 개선
}

\author{
이주은 · 김영진 · 김현정 · 남순현
}

경북대학교 치의학전문대학원 소아치과학교실

과잉치는 정상치아의 수보다 증가되어 나타나는 치아로서 상악 중절치 사이의 과잉치를 정중과잉치라 부른다. 정중과잉치 는 상악 전치의 맹출 장애를 포함하는 여러가지 병발증을 야기하지만 그 제거시기에 대해서는 아직 논란이 있다. 정중과잉치 에 의해 발생하는 병발증을 피하기 위해 가능한 조기에 발견하여 제거해야 한다는 주장과 외과적 발거에 따른 인접 치아의 손상을 최소화하기위해 상악 영구 전치의 치근발육이 완성된 후 제거해야한다는 주장이 있다.

이에 저자는 정중과잉치로 인해 회전된 상악 중절치를 가진 세 명의 환자들에서 중절치가 치근발육 초기단계에 있을 때 정 중과잉치를 제거함으로써 회전된 상악 영구중절치의 자연적인 개선이 보이는 바 이를 보고하고자 한다.

주요어: 정중과잉치, 회전된 중절치, 초기 치근발육 단계, 자연적인 개선 